\title{
A Tentative Study on the Strategies to Overcome Chinese Culture Aphasia in College English Teaching
}

\author{
Yan Liu \\ Tianjin University Renai College \\ Tianjin, China
}

\begin{abstract}
Under the background of the Belt and Road Initiative, China gets more involved in the international activities and Chinese culture has gained great attention around the world, but Chinese students usually find themselves in an awkward situation when introducing Chinese culture to foreigners in English. This phenomenon is known as Chinese Culture Aphasia which is first proposed by Cong Cong, a professor from Nanjing University. He used Chinese Culture Aphasia to show that Chinese students are lack of the ability to introduce Chinese culture in English during intercultural communication. Two factors account for Chinese Culture Aphasia, the first one is that students are not familiar with Chinese culture; the second one is that students haven't mastered the proper expressions of Chinese culture in English. With the continuous communication with foreign countries, Chinese culture should be provided in college English courses. Therefore, this thesis makes a systemic investigation on the strategies to overcome Chinese Culture Aphasia in college English teaching.
\end{abstract}

Keywords-Chinese Culture Aphasia; college English teaching; communicative competence

\section{INTRODUCTION}

Under the background of globalization, English plays an important role in international communication, so college English becomes a compulsory course of colleges and universities in China. The teaching aim of college English is to promote students' language skill and communicative competence. With the development of the Belt and Road Initiative, Chinese splendid traditional culture has gained great attention around the world, but Chinese students usually find that they do not know how to say the four great inventions of ancient China in English, how to introduce the thought of Confucius and Mencius to foreigners and how to diffuse Chinese excellent culture to the world. As we all know, culture plays an important role in communicating with others during the process of the intercultural communication, so college English courses should cultivate the students' intercultural communicative competence by following some cross-cultural communicating principles and teaching the essential part of Chinese culture in college English teaching. So this thesis will make a further study on Chinese Culture Aphasia in college English from the following aspects.

\section{THE RELATIONSHIP BETWEEN LANGUAGE AND CUlTuRE}

Culture is an important element in the intercultural communication and occurs in every aspect of our life, but it is difficult to give it a unique definition. Many scholars and researchers define culture from diverse perspectives such as linguistics, philosophy and sociology. Generally speaking, culture is a kind of social norm shared by a certain race or a certain country. Chastain divides culture into two different categories. The first one is the narrow culture, which is related to artistic or academic factors, such as history, literature, education, geography and science. The second one is the broad culture involving people's ways of life, such as habits, customs, and traditions and so on. Chastain believes the narrow culture can be learned in school and the broad culture will be acquired in social life. According to his point of view, culture can be educated during the process of language teaching and using.

Language and culture is indispensable to each other. Kramsch points out when language is used in the process of communication, it interacts with culture in various and complex ways. In fact, language is a kind of carrier for culture, the connotation of culture can be fully understood through the correct comprehension of the language. What's more, language would not be comprehended or expressed clearly without the background culture. Language is one part of culture and it contributes a lot to the formation and spreading of culture.

\section{INTERCULTURAL COMMUNICATION}

\section{A. Brief Introduction of Intercultural Communication}

Communicative competence was put forward by Hymes in 1979, who pointed out that grammatical competence was far from enough to help speakers achieve effective communication; speakers should know how to use appropriate language to fulfill their purposes. Intercultural communication competence refers to that a person has acquired efficient knowledge to interact with others effectively and achieve personal goals during cross-cultural communication. Intercultural Communication is a rather complex and systematic process of communication involving different cultures. Under the background of globalization, communication and cooperation from different cultures 
become increasingly inevitable, so intercultural communication competence plays a more and more important role.

\section{B. Principles for Successful Intercultural Communication}

There are three principles to ensure effective communication. The first one is to respect other country's culture. Mutual respect is the basis of successful communication because each nation has its unique culture. Showing respect to other country's culture actually means ethnic and cultural equality. The second one is the recognition of cultural identity. It is necessary to be proud of our own culture, self-image and communication style and then we will be respected by foreigners. The third one is cultural adaptation. When contacting with foreigners, we should appreciate the value of foreign culture and spread the excellent part of Chinese culture. We are supposed to seek the common ground of different cultures and accept the cultural differences. The three principles are crucial for effective intercultural Communication. Nowadays foreign culture has been strengthened too much in college English teaching, while Chinese culture has been neglected or lost, which will cause misunderstandings or failures in crossculture communication.

\section{CAuses for Chinese Culture Aphasia in COLLEGE ENGLISH TEACHING}

Chinese Culture Aphasia: Deficiencies in English Teaching in China, written by Professor Cong Cong, was issued in Guangming Daily in 2000. According to Professor Cong's theory, Chinese Culture Aphasia means that students don't know how to express Chinese culture properly in English during the process of intercultural communication, which will affect the result of communication and hinder students from improving communicative competence. Chinese Culture Aphasia widely occurs in colleges English teaching. In fact most students have a high level of English and they can talk about foreign countries' culture such as customs and festivals freely. When it comes to Chinese culture, they become speechless. Chinese Culture Aphasia not only makes us feel awkward, but also let us lose a great deal of opportunities to spread Chinese culture to the world, which will finally affect the exchanges between different cultures.

Two factors account for Chinese Culture Aphasia, the first one is that students are not familiar with Chinese culture, the second one is that students haven't mastered the proper expressions of Chinese culture in English. In the past, college English courses only focus on the study of foreign culture and ignore the contents of Chinese culture. It is not until recent years that Chinese educators pay more attention to the necessity of teaching Chinese culture and integrate it into the process of English teaching. Enhancing Chinese culture contents in college English teaching is a good way to foster students' cultural subjectivity and integrity and to improve students' competence to introduce Chinese culture in English fluently.

\section{PROPER OBJECTIVES FOR COLLEGE ENGLISH TEACHING}

College English teaching is an essential part of intercultural communication, whose final purpose is to cultivate students' communicative competence in daily life. Chomsky claims the competence to learn language including language competence and language performance. Hymes puts forward the communicative competence based on language competence. He further explains that language competence is not equal to language performance, language competence means knowing, and language performance means doing. The core of Hymes' concept of communicative competence is the adaptability of language, that is to say, using the suitable language in a specific social and cultural environment. He regards communicative competence as a part of cultural competence and focuses on the relationship between languages and cultures. Therefore, the fundamental goal of English teaching is to cultivate students' intercultural communication competence.

In the past, college English stresses on language skills and communicative competence. In the aspect of intercultural communicative competence, it only focuses on learning foreign culture, but ignoring the implementing of Chinese culture. Because of this kind of teaching mode, college students are incapable to introduce China culture when communicating with foreigners. College English Curriculum Requirements, issued by Chinese Ministry of National Education, advocates to improve college students' cultural awareness to promote the economic development and international activities. Objectives of college English teaching should be changed into the following mode in "Fig.1". This kind of objectives stresses on cultivating students' language skill and improving students' communicative competence, especially cross-cultural communicative competence so that students can learn from foreign culture and spread Chinese culture to the world.

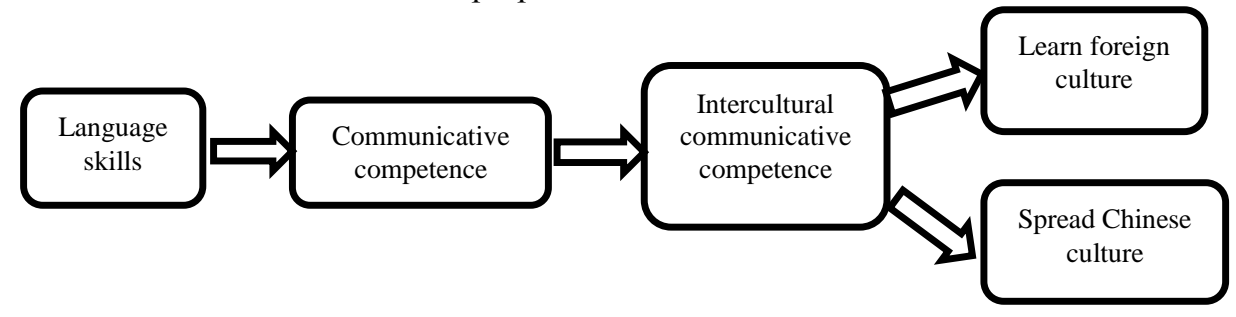

Fig. 1. Teaching Objectives for College English. 


\section{Strategies to OVercome Chinese CUlture APHASIA IN COLLEGE ENGLISH}

Syllabus is the guideline for the teaching process, confining the teaching purpose, teaching task, teaching contents, teaching process as well as teaching approach. College English syllabus shows that college English teaching is part of the humanities education. English is the most widely used language in the world; it becomes the carrier of foreign culture. English can help students to master advanced science and technology as well as the culture of foreign countries. It's the mission of College English teaching to cultivate students' cultural awareness so as to absorb the essence of foreign culture and to introduce Chinese culture to the world. It is necessary to reform College English teaching from the following aspects to overcome Chinese Culture Aphasia.

\section{A. Enriching the Teaching Contents with Chinese Culture}

Teaching contents refer to the materials used in one course to teach students the knowledge, skills and thoughts. Teaching materials are important mediums to teach language and culture, so they should be closely integrated with the teaching objectives. When choosing the appropriate English textbooks, educators should take the cultivation of students' language skills, cultural literacy and cultural awareness into consideration. Currently most textbooks are based on foreign culture mainly introducing foreign social and cultural life, but lack of the introduction of Chinese traditional culture and contemporary social life. College English teaching is in urgent need of suitable teaching materials covering the accurate expressions of Chinese culture and daily social life. Teachers should extend the contents of the teaching and make a comparative analysis between different cultures. The differences between foreign culture and Chinese culture not only reflect in words, phrases and sentences, but also reflect in history, values and customs. Chinese culture mainly focuses on humanistic spirit, such as striving for selfperfection, the harmonious relationship between Man and Nature. It is necessary to teach students the correct concept of Confucius and Mencius and the doctrines of Chinese Philosophy in English. These contents can help foreigners understand Chinese culture and provide a wide range of reference for English learners to communicate with foreigners.

\section{B. Adopting the Effective Teaching Approaches}

Effective teaching approaches will help teachers realize the teaching aim. Classroom teaching is the major form of teaching, teachers should make an effective use of teaching time to increase students' language and cultural knowledge. The comparative study between Chinese and foreign culture will help students have a deep insight into different cultures and guide them to get used to different cultures smoothly. Teachers should design interactive activities to help students acquire knowledge subjectively. Students can be divided into several groups to discuss certain topic or give presentations to exchange ideas and views about Chinese culture. This kind of teaching method can cultivate students' spirit of cooperation and improve their language proficiency. Modern technology should be applied in the process of teaching because videos, PPT, Wechat and internet technology can demonstrate Chinese traditional culture on diet, clothing, customs, philosophy and history vividly.

\section{Arranging Chinese Culture Experiencing Activities}

Colourful culture experiencing activities will increase students' interest in Chinese culture. Teachers can design some activities to create a good learning atmosphere for students to listen, speak and read more Chinese culture in English. Because the classroom teaching time is limited, teachers should guide students to make good use of the spare time to acquire Chinese culture through various channels. Teachers should encourage students to read English newspapers, such as New York Times, China Daily, 21st Century and so on to know more about the accurate expressions of Chinese culture. Teachers can recommend some excellent English books about Chinese culture. College should offer some selective courses about Chinese history, philosophy, customs and values. Students can make good use of libraries and Internet to search Chinese cultures they are interested in. Students can also participate in some activities to introduce Chinese culture to foreigners and invite foreign teachers to give some lectures on culture.

\section{Promoting College Teachers' Chinese Cultural Awareness}

College English teachers should improve their own levels in Chinese culture. Teachers must have a wide range of knowledge in English and know very well about the differences between Chinese and foreign cultures, so that they can teach the differences between Chinese and foreign cultures clearly and vividly. For example, when introducing Valentine's Day, they should also introduce Double Seventh Festival and make a specific explanation on the culture background of the two festivals. English teachers are the guiders to help students learn English knowledge and spread Chinese culture. Teachers should shoulder the responsibility of language teaching and spreading cultural inheritance. Improving teachers' Chinese culture awareness and English level plays a key role in promoting college English teaching.

\section{CONCLUSION}

China has a splendid culture in philosophy, literature, drama, gastronomy, Chinese medicine, festivals and customs. The brilliant achievements of Chinese culture attract increasing interests from all over the world. However, college English teaching ignores the importance of spreading Chinese culture. Many teachers think that as long as the students can speak English, they can talk about Chinese culture and achieve successful cross-cultural communication. Some teachers even think that the spread of Chinese culture is the responsibility of Chinese teacher, which has nothing to do with English teaching. Under the wrong guideline, Chinese students ignore the role of Chinese culture in intercultural communication, which finally leads to Chinese Culture Aphasia. They could not introduce Chinese culture to foreigners effectively and meet the failure in cross-cultural 
communication. After analyzing the reasons for Chinese Culture Aphasia, this article points out that the teaching of culture in college English should follow the principles of mutual respect, the recognition of cultural identity and cultural adaptation. What's more, it's necessary to choose excellent teaching materials, adopt effective teaching methods, provide colorful activities and improve teachers' Chinese cultural awareness so as to cultivate students' language skills and overcome Chinese Culture Aphasia.

\section{ACKNOWLEDGEMENT}

This article is the staged achievement of Research on Blended Learning under the Background of Internet Plus from Ministry of education, educational management information center (Project number:EIJYB2017-027). Meanwhile this article is the research achievement of Tianjin universities and colleges innovation project:Tianjin University Renai College Teaching Research Project (Project number:2017-1-4).

\section{REFERENCES}

[1] Brown.H.D, "Principles of language learning and teaching (3rd edition), " London: Prentice Hall Regents, 1994, PP. 47.

[2] Chastain, K, "Developing second language skills: theory to practice," Virginia:University of Virginia Press, 1976, PP. 388.

[3] Cong. C, "Chinese Culture Aphasia:deficiencies in English teaching in China," Guangming Daily, 2000, PP. 10-19.

[4] Hymes.D, "The communicative approaches to language teaching," Oxford:Oxford University Press, 1979, PP. 19.

[5] Hymes.D, "On communicative competence," Philadelphia, P.A.: University of Pennsylvania Press, 1971, PP. 16.

[6] Kramsch, Claire, "Context and culture in language teaching," Shanghai: Shanghai Foreign Language Education Press, 1999, PP. 217-240.

[7] Sapir.E, "Language: An introduction to the study of speech," M. Harcourt \&Brace Co, 1921, PP. 48.

[8] Taylor.E, "Primitive culture,” London: John Murray, 1974, PP. 127.

[9] Wilkins.D, "National syllabus," London: Oxford University Press, 1976.

[10] Yang.K.S, “The handbook of Chinese psychology," Oxford: Oxford University Press, 1996, PP. 479-498. 